\title{
Predation and Scavenging in the City: A Review of Spatio-Temporal Trends in Research
}

\author{
Álvaro Luna ${ }^{1}$, Pedro Romero-Vidal ${ }^{2,3}$ and Eneko Arrondo 2,4,* \\ 1 Asociación Brutal, Calle Cuna, 16, Primera Planta, 41004 Sevilla, Spain; alvalufer@gmail.com \\ 2 Department of Conservation Biology, Estación Biológica de Doñana-CSIC, 41004 Sevilla, Spain; \\ pedroromerovidal123@gmail.com \\ 3 Department of Physical, Chemical and Natural Systems, Universidad Pablo de Olavide, 41004 Sevilla, Spain \\ 4 Department of Applied Biology, Universidad Miguel Hernández, 03202 Elche, Spain \\ * Correspondence: bioeaf@gmail.com
}

check for

updates

Citation: Luna, Á.; Romero-Vidal, P.; Arrondo, E. Predation and

Scavenging in the City: A Review of Spatio-Temporal Trends in Research. Diversity 2021, 13, 46. https://doi. org $/ 10.3390 / \mathrm{d} 13020046$

Academic Editor: Luc Legal

Received: 22 October 2020

Accepted: 28 December 2020

Published: 25 January 2021

Publisher's Note: MDPI stays neutral with regard to jurisdictional claims in published maps and institutional affiliations.

Copyright: (c) 2021 by the authors. Licensee MDPI, Basel, Switzerland. This article is an open access article distributed under the terms and conditions of the Creative Commons Attribution (CC BY) license (https:// creativecommons.org/licenses/by/ $4.0 /)$.

\begin{abstract}
Many researchers highlight the role of urban ecology in a rapidly urbanizing world. Despite the ecological and conservation implications relating to carnivores in cities, our general understanding of their potential role in urban food webs lacks synthesis. In this paper, we reviewed the scientific literature on urban carnivores with the aim of identifying major biases in this topic of research. In particular, we explored the number of articles dealing with predation and scavenging, and assessed the geographical distribution, biomes and habitats represented in the scientific literature, together with the richness of species reported and their traits. Our results confirmed that scavenging is largely overlooked compared to predation in urban carnivore research. Moreover, research was biased towards cities located in temperate biomes, while tropical regions were less well-represented, a pattern that was more evident in the case of articles on scavenging. The species reported in both predation and scavenging articles were mainly wild and domestic mammals with high meatbased diets and nocturnal habits, and the majority of the studies were conducted in the interior zone of cities compared to peri-urban areas. Understanding the trophic role of carnivores in urban environments and its ecological consequences will require full recognition of both their predation and scavenging facets, which is especially desirable given the urban sprawl that has been predicted in the coming decades.
\end{abstract}

Keywords: anthropogenic food; diet; urban habitats; ecological functions; carnivorous

\section{Introduction}

Today, in an increasingly urbanized world, scientists, conservationists, and politicians agree that understanding the patterns that explain the biodiversity of cities and conserving this biodiversity along with its ecological functions is a priority within urban planning and nature conservation [1-4]. Typically, the growth of cities has been linked to biodiversity loss [5-7]. However, recent studies have demonstrated that cities are exploited by more species than previously thought (sometimes reaching higher population densities than in their original habitats [2,8]), and are even capable of hosting endangered species [9-12]. Factors related to cities that influence species composition and their exploitation of this novel ecosystem include urban structure and development $[6,13,14]$, different types of pollution found in cities (e.g., noise [15], artificial light [16], chemical contamination [17]), and the existence of refuge and food sources [18]. For vertebrates such as birds, urbanization acts as a filter, but a combination of traits, including phenotypic and behavioral flexibility, dispersal strategies, and niche flexibility, allow a certain number of species to exploit cities [19-22]. The same can be attributed to the other most common vertebrates in cities, mammals, as certain reproduction-related traits and their behavioral flexibility favor the successful use of cities for a limited number of taxa $[23,24]$. Other factors influencing urban species composition include diet-related aspects, as species that thrive in cities usually 
can feed on a wide variety of foods, which sometimes are directly or indirectly related to humans $[19,25]$. Meat is an abundant and heterogeneously distributed food resource present in urban and peri-urban areas [22,26-28]. It appears in the form of both domestic and wild vertebrates, and also as carrion (i.e., roadkill and anthropogenic refuse $[29,30]$ ). This mostly occurs in cities with inefficient waste treatment, but also in landfills and ports located in typical peri-urban areas [26-28]. The diet of several urban carnivores has been assessed, and as such we have gained an appreciation both for the items they consume and the prevalence of the different sources of food. Thus, different prey form part of the urban diet of raptors, mammals, and other carnivores [31,32]. Moreover, a growing amount of research reports the progressive inclusion of human refuse in the diet of urban animals in the form of organic and inorganic garbage [33-35]. In general, urban carnivores range from obligate carnivores, such as the barn owls (Tyto alba) [31], to generalist omnivores, such as the red fox (Vulpes vulpes) [36] and corvids [37], which eat meat, vegetables, fruits, and berries, with different preponderance of each food source depending on the species. Therefore, urban carnivorous species can consume meat (i.e., vertebrate biomass) in two different ways: by predation (actively hunting their prey) $[32,38,39]$ or by scavenging (eating the remains of already dead animals or garbage) $[27,40]$. Between these two extremes, several species act as facultative scavengers, consuming both live prey and carrion or human refuse, such as the coyotes (Canis latrans) [41] and gulls [42].

The feeding behavior observed by carnivores in cities contributes to the structure of natural urban communities, for example, by limiting the population size of their prey [43]. In some cases, they can provide benefits to humans, especially when they prey upon certain synanthropic species (e.g., feral pigeons [44] or rodents [31]). An example is found in Indian cities, where the consumption of stray dogs by leopards is expected to reduce disease transmission [45]. However, the constant availability of refuse can also alter the diet preferences of carnivores in anthropized areas, affecting the trophic dynamics and population densities of urban carnivores and their potential prey [29,30,46-48]. Regarding scavengers, they play additional and concrete roles in cities, by contributing to accelerating the process of carrion decomposition [49,50]. Moreover, the consumption of subsided food and the high abundance of prey in cities can have a profound effect at the individual level, influencing the growth rate, body condition, and survival of carnivores. In addition, there are also obvious negative consequences, for example, when feeding on resources with low nutritional value or indigestible waste [30,51]. Furthermore, carnivores in cities are also confronted with new threats, common to the urban environment, such as an increased probability of collision with buildings or vehicles [27,52,53]. Attending to this, cities may become ecological traps for certain species [54-56]. However, although mostly unstudied, urban exploitation by carnivores may play a potential role in their conservation, as observed for some scavengers feeding mostly on human subsided food [57,58].

In recent years, different reviews have analyzed the knowledge generated within urban ecology, and have proposed how this discipline can advance along multiple research directions [59,60]. Focusing on urban biodiversity studies, McPhearson et al. [61], established the acquisition of a better understanding of how the ecological community structure, including invasive species, affects ecosystem dynamics, structure, and function in cities as a future priority. Moreover, Magle et al. [60] revealed how urban ecology research is biased towards birds and mammals, is generally focused on behavior and conservation issues, and is carried out to a lesser extent in less developed countries. Apparently, studies focused on the diet of carnivores, especially scavengers, seem to have been of little priority, despite the importance they may have for understanding urban wildlife communities, the ecosystem services they provide, and the potential conservation implications.

In this study, we aim to review the scientific literature on urban carnivores, distinguishing between the predatory and scavenging function of this ecological group, to offer an integrative first approach about the spatio-temporal trends observed in the scientific literature focused on this topic. Concerning the information contained in the articles, we also explored in which locations within the urban matrix the studies were conducted (the 
interior of the city vs. the peri-urban areas), and, in the case of scavengers, we analyzed if the studies were carried out based on natural conditions or developing experiments with carrion provided by the researchers. Moreover, we explored the diversity of carnivores reported in the reviewed articles, together with the primary physical and behavioral traits that may contribute to explaining their presence in the reviewed studies. Considering that scavenger impact on ecology has been little studied until recent decades [62], we hypothesize that most of the published research concerning carnivores' diet and presence in cities has been devoted more to predators than to scavengers. In addition, following the suggestions from Magle et al. [60] about the current bias in urban ecology research on developed countries, we try to confirm that this trend also occurs in the case of carnivorous studies in cities. Additionally, we consider that the carnivores and scavenger richness obtained in our review would be higher, with many species recorded in studies from Africa, Latin America and Asia. To test this hypothesis, the greater species richness of tropical regions in which most of the developing countries are located $[63,64]$ must be considered, as this logically leads to greater chances of more species potentially exploiting cities. Moreover, the poorer waste management of developing countries offers greater possibilities for feeding for scavengers in the form of all types of refuse, contributing to the presence of different scavengers. Lastly, attending to the characteristics of the vertebrates that most commonly exploit cities, we predict that the most represented predators and scavengers will be synanthropic species, mainly mammals and birds, with nocturnal habits that would permit these species to avoid potential conflict with humans.

\section{Materials and Methods}

\subsection{Systematic Literature Review}

To review the scientific literature published about urban carnivores we followed the guidelines proposed by Haddaway et al. [65] and Lozano et al. [66]. First, we studied peerreviewed articles published in journals available on Web of Science and Scopus databases. The search was applied to the title, without selecting any date range. We considered the inclusion of the grey literature, taking into account the contribution of these additional sources for systematic reviews $[67,68]$. However, in our searches, we did not find these technical reports, conferences and similar publications, and so we only included scientific articles. To avoid the heterogeneity inherent to different observers, only one of the authors searched the databases, by using a search string that combined different terms related to predation and scavenging in urban environments. We conducted two different searches including the terms (urban* OR city*) AND (scaveng* OR predat*). Second, we completed our database, both in the case of urban predation and urban scavenging, by applying a "snowball" procedure, including additional articles found in the previously selected reference lists [66]. Third, we completed the dataset on predation and scavenging by including more articles found in a complementary non-systematic search, based mainly on Google Scholar.

We explored the content of the compiled articles with a two-step process. First, we screened titles and abstracts to ensure we only included articles focused on the urban predation and scavenging diet of urban wildlife. Accordingly, studies located in human dominated but non-urban sites, for example, those conducted in transformed landscapes such as agricultural areas, were excluded. Moreover, we also left out those nature reserves located in other anthropized locations with less urban development. Equally, articles focused on human scavenging in garbage dumps (picking through garbage for food scraps), and those referring to forensic science were discarded. Secondly, we read the main text of the articles to see how and to what extent urban predation/scavenging was addressed. We considered a species to be an urban predator when it was recorded in urban environments actively preying on vertebrates (including eggs) while we considered a species to be an urban scavenger when it was recorded consuming carrion (including human waste). Regarding the topic in the studies we reviewed, in our final list, we discarded those studies based on scavenger species but exploring other aspects of their biology and ecology 
different from their diet, as well as non-empirical studies (i.e., reviews, conceptual papers and anecdotal short notes without detailed data to use in further analyses).

\subsection{Data Extraction}

From the retained articles, we extracted the following information: (i) year of publication; (ii) study site, including the biome (based on the classification used by Olson et al. [69] to define major habitat types), continent, country and city studied; (iii) population size of the city during the year of the study; (iv) sector of the city considered, classifying the articles as urban, (those conducted in the interior of the cities), and peri-urban (i.e., peripheral landfills and urban nature reserves surrounding cities, and residential neighborhoods); (v) studied taxa, at class, order and species level; (vi) richness of predator/scavenging species (this was calculated only in those studies that did not focus on the activity of a single species). Then, for each reported species, we identified (vii) the carnivore level, calculated as the proportion of diet based on vertebrates (including eggs). To calculate this, in the case of mammals and birds, we summed all dietary variables which included vertebrates, from Wilman et al. [70], (viii) average body mass of the species in grams and (ix) daily activity (mainly diurnal or nocturnal). For reptiles, we used complementary dietary bibliography [71-75]. Solely for scavengers, we included whether the study was conducted thinking specifically about scavenging or, in contrast, if this was merely an aspect within studies focused on diet in a broader sense. Additionally, when the studies were focused on scavenging, we added information regarding the origin of the carrion, to clarify whether the species was purposely fed with certain carrion for research purposes (fish heads, bird carcasses from domestic or wild animals, garbage) instead of consuming the refuse scattered in the city.

\subsection{Statistical Analyses}

We conducted General Linear Models (GLMs; Poisson error distribution and log link function) to explore the characteristics of the species that were most frequently studied in urban predation and urban scavenging studies. In order to do this, we only considered those studies that had analyzed the activity of one or more species within the city or surrounding area. We created two sets of models separating information about urban predation and urban scavenging studies. In both sets, the explanatory variables were the number of times each species appeared in the articles found during the bibliographic review. As explanatory variables we included: (a) taxonomic class; (b) taxonomic order; (c) carnivory level; (d) body mass; (e) daily rhythm. In both sets of models, we explored all combinations of the variables, considering only additive effects. To discuss the results, we followed an Information Criterion Approach. We selected the most parsimonious models (i.e., lowest AICc). In addition, we selected all models with a difference of $\triangle \mathrm{AICc}<2$ compared to the most parsimonious model [76]. As the information criterion does not inform about the absolute predictive capacity of the models, we later discarded those selected models with little-relevant explanatory variables (i.e., the values at the $85 \%$ confidence interval which overlapped with 0 [76]. We used an $85 \%$ confidence interval to avoid the possible loss of valid models by using more restrictive and conservative approaches such as the $95 \%$ confidence interval [77]. We explored the overdispersion of selected models using the AER package [78]. Finally, to analyze how well our models fit, we calculated the explained deviance $\left(\mathrm{D}^{2}\right)$. All statistical analyses were performed in the $\mathrm{R}$ v.3.6.1 statistical platform [79].

\section{Results}

The results using predat* as the search term returned a total of 32 items, while using scaveng* offered only five results. Including only the articles found in the enclosed review, we observed that most predation articles were published after the 2000s, and all scavenging articles had been published in the last 10 years, with scavenging remaining in the background in the studies focused on carnivores in cities, although proving to be a nascent 
interest as a study topic (Figure 1). By adding the articles obtained with complementary searches (snowball and other sources), we increased the number of studies, obtaining a final dataset of 95 articles for urban predation and 47 articles for urban scavenging (see Tables S1-S4 for details). Regarding the articles focused on urban scavenging, at least 13 of those included in the final list clearly demonstrated that these studies were carried out under experimental conditions, providing the scavengers with carrion (mainly farm animals) instead of evaluating the consumption of refuse scattered in cities.

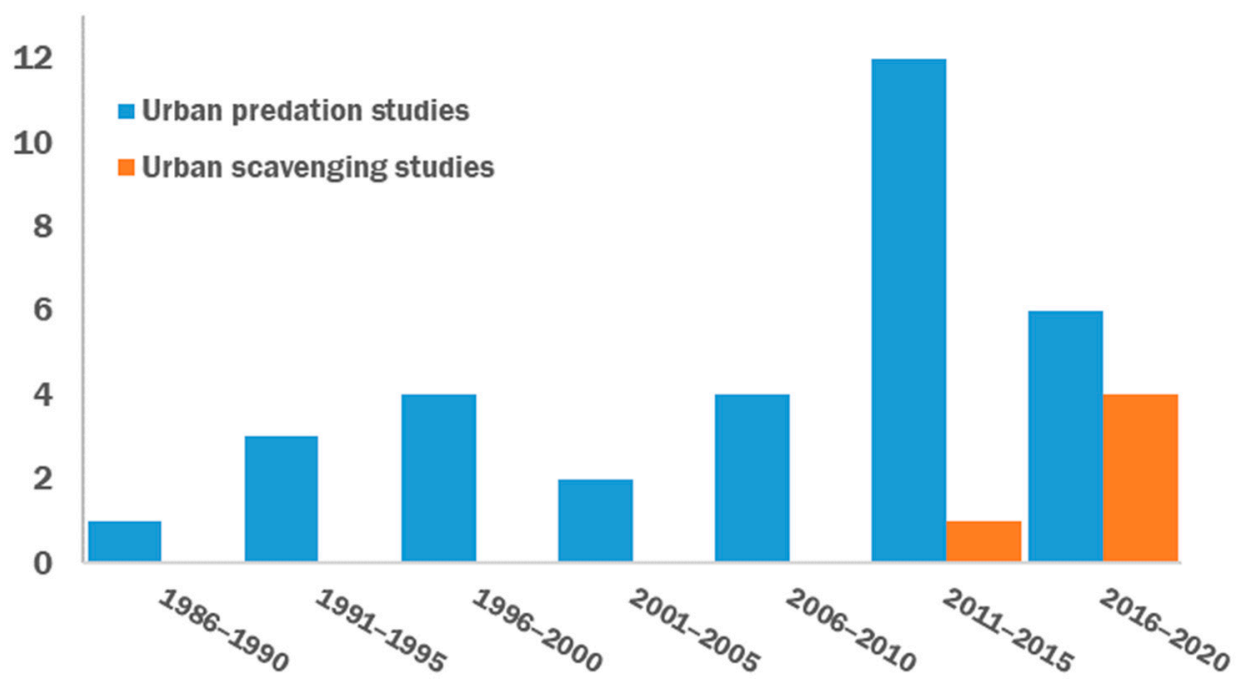

Figure 1. Temporal comparison between urban predation and urban scavenging published studies, based on the total of articles retained strictly from the systematic review, conducted with closed search.

We found that most of the studies analyzed were developed in temperate biomes (68.4\% of the predation studies and $50 \%$ of the scavenging studies), followed by urban predation studies in Mediterranean forests $(11.58 \%)$ and by tropical biomes $(22.92 \%)$ in urban scavenging studies. Regarding the geographical locations, in the case of urban predation, 35 studies were performed in Europe, 32 in America, 17 in Oceania, 6 in Asia and 5 in Africa, with the United States of America $(n=20)$ and Australia $(n=13)$ accumulating the highest number of studies (Figure 2A, S1). On the other hand, urban scavenging studies were carried out in America in 12 cases, 10 in Europe, 9 in Oceania and Asia, and 8 in Africa. As for urban scavenging studies, Australia $(n=9)$ and the United Kingdom $(n=5)$ were the countries with the most published papers (Figure 2B, S2). The population size of the cities studied ranged from 3.54 to 9.1 million for predation studies and 3500 to 9 million for scavenging studies, which produced no significant difference $(t=1.71$, $\mathrm{df}=44.46$, $p$-value $=0.095)$. Regarding the location where the studies were focused, we detected that the majority were conducted in the interior of cities or included both urban and peri-urban areas (Figure 3).

Of the 95 urban predation studies, 93 contained information on at least one species (the remaining two were focused on eggs predation without identifying the predators). In total, we recorded 100 species in the reviewed urban predation studies (62 birds, 28 mammals and 10 reptiles; see Table 1 for a complete list). The most represented orders were Passeriformes $(n=23)$, Accipitriformes $(n=16)$ and Carnivores $(n=16)$. Seven species appeared as predators in five or more articles: Felis catus $(n=21)$, Falco tinnunculus $(n=8)$, Tyto alba $(n=8)$, Vulpes vulpes $(n=8)$, Canis latrans $(n=6)$, Canis lupus familiaris $(n=5)$, and Falco peregrinus $(n=5)$ (Figure $2 \mathrm{~A})$. Regarding urban scavenging, we registered 49 species (25 birds, 21 mammals, and 3 reptiles) (Table 2), with Carnivores being the most represented group $(n=11)$, followed by Passerines $(n=10)$ and Accipitriformes $(n=9)$. The number of species is lower in comparison with those studies focused on predation, a logical result considering the smaller number of studies found on scavenging. All studies on scavenging (47) contained information on one or more species. Urban scavengers appearing in five 
or more different articles, were Vulpes vulpes $(n=11)$, and two domestic mammals, Felis catus $(n=9)$ and Canis lupus familiaris $(n=7)$ (Figure $2 \mathrm{~B})$. From the total of articles reviewed on predation, 21 contained sufficient information to calculate species richness (mean and standard deviation: $5.36 \pm 5.26$; range: $2-20$ species per study), while 9 of the scavenging studies contained such information (mean and standard deviation: $7.00 \pm 2.54$; range: 3-10 species per study).

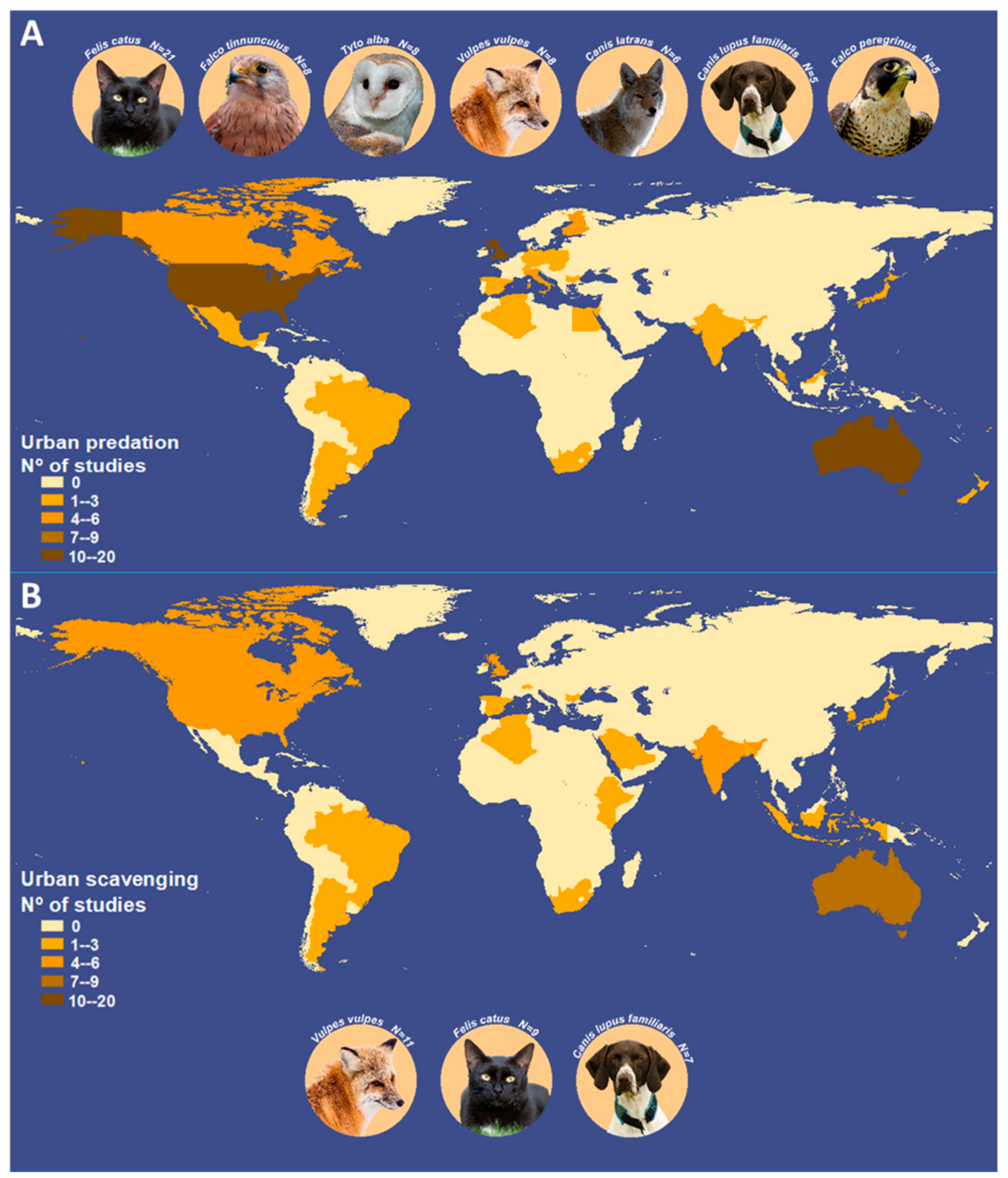

Figure 2. Number of urban predation (A) and scavenging (B) studies per country. Darker colors show high number of articles found for a given country, ranging from 0 to 20 . The circles represent the species most reported in the articles (appearing on 5 or more occasions), ordered from most-reported to least-reported, from the top left corner. Pictures by: Manfredrichter, Ruthmcd, Miles, Wilda3, Skeeze and Ebor. 


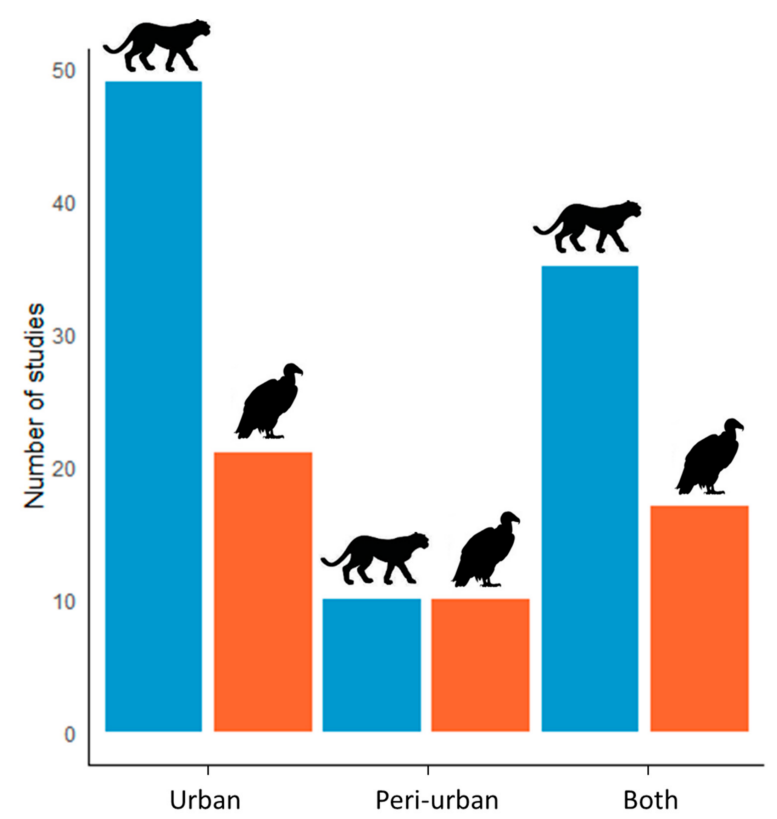

Figure 3. Number of studies conducted in urban and/or peri-urban areas on predation (blue bars) and scavenging (orange bars).

Table 1. Complete list of predators recorded in all articles reviewed. $\mathrm{N}$ is the number of studies that include each species.

\begin{tabular}{|c|c|c|c|c|c|}
\hline Species & $\mathbf{N}$ & Species & $\mathbf{N}$ & Species & $\mathbf{N}$ \\
\hline Felis catus & 21 & Buteo lineatus & 1 & Sciurus carolinensis & 1 \\
\hline Falco tinnunculus & 8 & Buteo platypterus & 1 & Sciurus niger & 1 \\
\hline Tyto alba & 8 & Dacelo novaeguineae & 1 & Sciurus vulgaris & 1 \\
\hline Vulpes vulpes & 8 & Dumetella carolinensis & 1 & Tamias striatus & 1 \\
\hline Canis familiaris & 5 & Falco columbarius & 1 & Tamiasciurus hudsonicus & 1 \\
\hline Canis latrans & 6 & Falco sparverius & 1 & Vulpes macrotis mutica & 1 \\
\hline Falco peregrinus & 5 & Gralina cyanoleuca & 1 & Chaetophractus villosus & 1 \\
\hline Accipiter cooperii & 4 & Gymnorhina tibicen & 1 & Geranoetus polyosoma & 1 \\
\hline Strix aluco & 4 & Ictinia plumbea & 1 & Athene brama & 1 \\
\hline Martes foina & 4 & Larus delawarensis & 1 & Athene cunicularia & 1 \\
\hline Rattus rattus & 4 & Larus marinus & 1 & Bubo ascalaphus & 1 \\
\hline Corvus brachyrhynchos & 3 & Larus michahellis & 1 & Bubo virginianus & 1 \\
\hline Cyanocitta cristata & 3 & Leucophaeus atricilla & 1 & Strix varia & 1 \\
\hline Asio otus & 3 & Manorina inelanocephala & 1 & Conepatus chinga & 1 \\
\hline Athene noctua & 3 & Passer domesticus & 1 & Pseudalopex gymnocercus & 1 \\
\hline Procyon lotor & 3 & Pica pica & 1 & Antechinus stuartii & 1 \\
\hline Canis lupus dingo & 2 & Quiscalus quiscula & 1 & Genetta tigrina & 1 \\
\hline Accipiter gentilis & 2 & Stephanoaetus coronatus & 1 & Glaucomys volans & 1 \\
\hline Falco femoralis & 2 & Sturmis vulgaris & 1 & Mephitis mephitis & 1 \\
\hline Larus argentatus & 2 & Troglodytes aedon & 1 & Mustela itatsi & 1 \\
\hline Molothrus ater & 2 & Zosterops lateralis & 1 & Puma concolor & 1 \\
\hline Rupornis magnirostris & 2 & Corvus cornix & 1 & Dasypus hybridus & 1 \\
\hline Strepera graculina & 2 & Chroicocephalus ridibundus & 1 & Leopardus colocolo & 1 \\
\hline Ninox strenua & 2 & Corvus corax & 1 & Galictis cuja & 1 \\
\hline Didelphis virginiana & 2 & Perisoreus infaustus & 1 & Pantherophis emoryi & 1 \\
\hline Pseudocheirus peregrinus & 2 & Garrulus glandarius & 1 & Philodryas olfersii & 1 \\
\hline Elaphe obsoleta lindheimerii & 2 & Dendrocopos major & 1 & Phrynops geoffroanus & 1 \\
\hline Accipiter nisus & 1 & Corvus corone & 1 & Psammophilus dorsalis & 1 \\
\hline Acridotheres tristis & 1 & Corvus frugilegus & 1 & Pseudonaja affinis & 1 \\
\hline Aphelocoma californica & 1 & Corvus monedula & 1 & Thamnophis sirtalis & 1 \\
\hline Aquila verreauxii & 1 & Caracara plancus & 1 & Paraphimophis rusticus & 1 \\
\hline Buteo jamaicensis & 1 & Circus buffoni & 1 & Erythrolamprus poecilogyrus & 1 \\
\hline Geranoaetus melanoleucus & 1 & Circus cinereus & 1 & Xenodon dorbignyi & 1 \\
\hline Parabuteo unicinctus & 1 & & & & \\
\hline
\end{tabular}


Table 2. Complete list of scavengers recorded in all articles reviewed. $\mathrm{N}$ is the number of studies that include each species.

\begin{tabular}{|c|c|c|c|c|c|}
\hline Species & $\mathbf{N}$ & Species & $\mathbf{N}$ & Species & $\mathbf{N}$ \\
\hline Vulpes vulpes & 11 & Cyanocitta cristata & 1 & Haliastur sphenurus & 2 \\
\hline Felis catus & 9 & Didelphis virginiana & 1 & Procyon lotor & 2 \\
\hline Canis lupus familiaris & 7 & Erinaceus europaeus & 1 & Varanus varius & 2 \\
\hline Corvus orru & 4 & Geococcyx californianus & 1 & Ciconia ciconia & 1 \\
\hline Milvus milvus & 2 & Haliaeetus leucocephalus & 1 & Corvus coronoides & 1 \\
\hline Canis latrans & 3 & Lanius ludovicianus & 1 & Corvus macrorhynchos & 1 \\
\hline Corvus corone & 3 & Laridae spp. & 1 & Corvus splendens & 1 \\
\hline Crocuta crocuta & 3 & Larus dominicanus & 1 & Varanus bengalensis & 1 \\
\hline Cynictis penicillata & 3 & Larus michahellis & 1 & Varanus salvator & 1 \\
\hline Pica pica & 3 & Larus novaehollandiae & 1 & Pica hudsonia & 1 \\
\hline Rattus spp. & 3 & Larus pacificus & 1 & Scincidae spp. & 1 \\
\hline Chroicocephalus novaehollandiae & 2 & Lutreolina crassicaudata & 1 & Scirus vulgaris & 1 \\
\hline Coragyps atratus & 2 & Martes foina & 1 & Sciurus carolinensis & 1 \\
\hline Corvus brachyrhynchos & 2 & Mephitis mephitis & 1 & Sciurus niger & 1 \\
\hline Galerella sanguinea & 2 & Mustela putorius & 1 & Sus scrofa & 1 \\
\hline Haliaeetus leucogaster & 2 & Necrosyrtes monachus & 1 & Sylvilagus floridanus & 1 \\
\hline Haliastur indus & 2 & Neophron percnopterus & 1 & Tamias striatus & 1 \\
\hline Milvus migrans & 2 & Terrapene carolina & 1 & & \\
\hline
\end{tabular}

In urban predation and scavenging studies, the most recorded species were those with meat-based diets and nocturnal activity (Table 3). In both sets, there were other models that included the explanatory variables carnivorous level and class (Table 3), at only a few tenths above the threshold of $2 \Delta$ AICc. The selected models explained an important fraction of the deviance ( 0.27 in the case of the urban predation model and 0.29 in the case of the urban scavenging model) (Table 4). Both models showed very low values of over-dispersion ( 0.63 in the case of the urban predation model and 0.18 in the case of the urban scavenging model).

Table 3. AIC-based model selection to assess the characteristics of the scavenger species most recorded. Only models with informative variables are included. Model selected is represented in bold. Number of estimated parameters (K), AICc values, AICc differences ( $\triangle \mathrm{AICc}$ ) compared to the highest ranked model (i.e., the one with the lowest AICc), Akaike weights $(\mathrm{AICcWt})$, Cumulative weight (CumWt) and the variability of the models explained by the predictors $\left(\mathrm{D}^{2}\right)$ are represented.

\begin{tabular}{|c|c|c|c|c|c|c|c|}
\hline Response Variable & Models & $\mathbf{K}$ & AICc & Delta_AICc & AICcWt & Cum.Wt & $\mathrm{D}^{2}$ \\
\hline \multirow{9}{*}{ Urban predation } & Carnivore level + Daily rhythm & 3 & 347.804 & 0.000 & 0.798 & 0.798 & 0.27 \\
\hline & Carnivore level + Class & 4 & 350.596 & 2.792 & 0.198 & 0.996 & \\
\hline & Daily rhythm & 2 & 358.698 & 10.893 & 0.003 & 0.999 & \\
\hline & $\begin{array}{c}\text { Carnivore level + Order + Daily } \\
\text { rhythm }\end{array}$ & 17 & 362.022 & 14.217 & 0.001 & 1.000 & \\
\hline & Carnivore level + Order & 16 & 365.539 & 17.735 & $<0.001$ & 1.000 & \\
\hline & Carnivore level & 2 & 368.716 & 20.912 & $<0.001$ & 1.000 & \\
\hline & Order & 15 & 376.378 & 28.574 & $<0.001$ & 1.000 & \\
\hline & Class & 3 & 377.075 & 29.271 & $<0.001$ & 1.000 & \\
\hline & NULL & 1 & 387.227 & 39.423 & $<0.001$ & 1.000 & \\
\hline \multirow{8}{*}{ Urban scavenging } & Carnivore level + Daily rhythm & 3 & 156.082 & 0.000 & 1.000 & 0.802 & 0.29 \\
\hline & Carnivore level + Class & 4 & 159.505 & 3.423 & 0.181 & 0.145 & \\
\hline & Daily rhythm & 2 & 161.964 & 5.882 & 0.053 & 0.042 & \\
\hline & Carnivore level + Order & 2 & 164.850 & 8.768 & 0.012 & 0.010 & \\
\hline & Carnivore level & 1 & 171.257 & 15.176 & 0.001 & $<0.001$ & \\
\hline & Order & 3 & 172.044 & 15.962 & $<0.001$ & $<0.001$ & \\
\hline & Class & 18 & 203.664 & 47.582 & $<0.001$ & $<0.001$ & \\
\hline & NULL & 19 & 209.212 & 53.131 & $<0.001$ & $<0.001$ & \\
\hline
\end{tabular}


Table 4. Results of the General Linear Models (Poisson error distribution and identity linkage) selected to explain the number of studies in which each species appears. The estimate of the parameters (including the sign), the standard error of the parameters, the degrees of freedom of the models (DF) and variability explained by the models are represented $\left(\mathrm{D}^{2}\right)$.

\begin{tabular}{|c|c|c|c|c|c|}
\hline Models & Explanatory Variables & Estimate & Std. Error & DF & $\mathrm{D}^{2}$ \\
\hline \multirow{3}{*}{ Urban predation } & (Intercept) & -0.079 & 0.161 & \multirow{3}{*}{98} & \multirow{3}{*}{0.27} \\
\hline & Carnivore level & 0.007 & 0.002 & & \\
\hline & Nocturnal & 0.719 & 0.148 & & \\
\hline \multirow{3}{*}{ Urban scavenging } & (Intercept) & -0.018 & 0.275 & \multirow{3}{*}{42} & \multirow{3}{*}{0.29} \\
\hline & Carnivore level & 0.010 & 0.003 & & \\
\hline & Nocturnal & 0.612 & 0.207 & & \\
\hline
\end{tabular}

\section{Discussion}

\subsection{Temporal Trends of Predation/Scavenging Studies in Urban Ecology}

In this review, we explored the scientific literature focused on urban predators and scavengers. A positive observation is that there is a growing interest in these subject as a study topic, as the articles have been increasing in number over the years. To strengthen the result that the topic is gaining interest, it can be noted that most of the articles reviewed had predation and scavenging as their main subject, and they did not relegate this aspect to a secondary interest within other subjects. Moreover, digging further into the general information assessed in the articles published, we can observe that most of the research studied not only peri-urban areas but also the interior of the cities, showing a clearer understanding of the activities of predators and scavengers in the cities themselves [80,81]. However, it is also true that in the case of scavenging studies, a non-negligible amount was carried out under experimental conditions $[49,50,82,83]$, so it would be of interest to devote more effort to understanding the interaction of certain species with actual available refuse. When explaining the reason behind the temporal growth in the number of studies on predation and scavenging in cities, we consider that the general growth of urban ecology, as a relatively new discipline, may be also responsible for this positive trend $[59,84]$. Nevertheless, the gap detected between the number of articles referring to predators and scavengers reveals that less attention was devoted to urban scavenging, confirming that this topic has been widely overlooked and, to date, is lesser known and understood. To no surprise, our bibliographic search on urban scavenging only returned five articles, and despite having completed the dataset through the "snowball" and the complementary search, the total number of articles referring to urban scavenging was half of that found for urban predation. In any case, we cannot ignore that, in general, studies focused on scavenging ecology are fewer, with an increase only in recent years [62], a reality which may help to explain our result. Clearly, our search on both subjects (e.g., urban predators and scavengers) does not include the total studies on both subjects; however, the review we conducted shows that the number of studies is not related to the relevance that scavenging studies may acquire, attending to their ecological importance and the ecosystem services they might provide in cities [62,85].

\subsection{The Bias Extant in Urban Predation and Scavenging Studies across Regions}

We confirmed a geographical bias in the reviewed studies across different regions of the world [60], as the information is concentrated in a few specific countries while it remains scarce for other vast regions, especially the less developed ones (see Figure 2). We must address the simple fact that the lower scientific research activity detected in developing countries [86] may contribute to explaining the scarcity of articles focused on predation and scavenging in cities located in less developed countries. Moreover, we observed that a great variety of biomes are clearly underrepresented, even in regions where studies have been conducted, confirming the existence of a second spatial gap. Curiously, the regions which are less represented in the reviewed articles (mainly in Africa, Asia and Latin America) have urban areas that accumulate greater quantities of garbage 
and carrion in the streets (their poor management systems prevent them from handling the enormous amount of waste produced [87]), and thus are potentially suitable areas to study the interaction between wildlife and refuse. Additionally, the sites with worst waste collection are sites with potentially higher populations of synanthropic species (such as rats [88]) and semi-domestic animals roaming in the streets, and are thus locations where, hypothetically, more carnivores can thrive $[45,89]$.

\subsection{Predator and Scavenger Species in Urban Environments}

Considering all the articles reviewed, we recorded a total of 100 predator species (found in 95 studies) and 49 scavengers (found in 47 studies). Some of these species are repeated, and appear in both sets of considered articles, given their opportunistic feeding habits that can lead them to both hunt and scavenge. Despite the greater number of species reported as predators, this may not necessarily be due to a greater presence of predators in cities, but rather to the fact that we only found around half the number of studies on scavenging compared to those on predation, thus reducing the possibility of detecting more species. This reinforces the need to increase research devoted to scavenging in cities. Life history, and ecological and behavioral traits predispose certain species to exploit urban environments $[20,24,90,91]$, and the development of cities and associated impacts can limit or facilitate the successful exploitation of them by wildlife [92,93]. The reviewed studies do not offer sufficient data to analyze the influence of the elements associated with urbanization (i.e., noise, artificial light or human activities) on carnivorous occurrence. However, data extracted from the studies with ample information regarding predator and scavenger richness in cities suggest that the carnivore guild is reduced in urban environments, with an important range of variability. Further research is needed to gain knowledge of how certain characteristics inherent to the structure and environment of cities influence the occurrence of more carnivores. With regard to this, we suggest the inclusion of variables related to noise and acoustic pollution in studies related to urban carnivores, which are practically absent in the reviewed articles, despite their recognized impact on species exploiting cities [15-17]. In any case, we cannot forget that urban areas are normally characterized by lower biodiversity than wildlands [2,5-7], so it is expected that not all of the potential species inhabiting the surrounding areas of each city will be able to successfully exploit these human-dominated ecosystems.

Additionally, our results showed that the most encountered species are those with a highly meat-based diet, and, consequently, less consumption of vegetables or insects. Urban predators find a high availability of food associated with human environments (i.e., pets, pigeons and rats), which aids them in seeing that their trophic needs are easily met $[36,94,95]$. On the other hand, garbage constitutes an accessible resource which not only attracts obligate scavengers such as black vultures (Coragyps atratus) [30], but also seems to serve as a complement to the predators settled in the city. This is corroborated by the fact that most of the species detected in the scavenging studies also appeared on the predator list (Figure 2 and Tables 1 and 2). Regarding other traits pertaining to the carnivores recorded in the studies, most of the reported species showed nocturnal habits, coinciding with hours of less human activity. Thus, our results suggest that urban carnivores take advantage of periods of less human disturbance to satisfy their feeding needs. In addition, although the most frequent species in our review were a medium size (Figure 2), the selected models did not include the body mass variable, which may be attributed to our relatively small sample size.

Regarding taxonomic features, most of the species recorded in the articles are mammals and birds (mainly raptors), which may be explained by the general bias present in urban ecology towards these groups [60]. In the case of predators and scavengers, there were not many options beyond them; however, we still found some articles focused on Asian monitor lizards [96,97], and others that include these reptiles as scavengers among other species [94]. Despite that, the selected models did not include any taxonomic classification, but the model that included the class variable proved to be better than the null 
model, being very close to the threshold of 2 points of AICc. This, added to the fact that the presence among the main species detected in both cases includes mammals such as the red fox, and the domestic dog and cat, makes us suspect that there may indeed be a taxonomic tendency among carnivores to adapt to cities. However, available data in the reviewed articles were not sufficient to demonstrate this.

\subsection{Conservation Implications}

Regarding our results, we consider that it is necessary to devote more effort to assessing the role that cities may play for scavengers, in order to obtain a more complete understanding of the ecological and conservation implications which may result from the urban predatory and scavenging habits of wildlife [11,33]. In this sense, from a conservation point of view, species management strategies should consider the role of cities for predators and scavengers, due to the short- and long-term influence (both positive and negative) that their presence in cities and the consumption of living prey and refuse may have, at both individual and population levels [28-30,45]. Due to natural habitat loss, the probability of larger mammals colonizing urban environments may increase, as evidenced by the anecdotal but growing data shown for leopards (Panthera pardus), tigers (Panthera tigris) and lions (Panthera leo persica) in India [98-100]. In this sense, the increase in the number of medium- to large-size predators feeding in cities may lead to an increase of potential human-wildlife conflicts, which will ultimately call for a better understanding of their presence in humanized areas. Furthermore, cities should be treated as other habitats in conservation projects relating to endangered carnivores, taking into account that they undoubtedly use this type of ecosystem. Thus, ignoring the pros and cons that result from the species' exploitation of urban environments would be negligent.

Lastly, we must reflect on the multiple interpretations from the nature conservationist point of view that the prominent presence of cats and dogs in both reviews offers. First, the predominance of the same species among the most recorded predators and scavengers is a logical consequence of their close association to humans, who have aided in their expansion wherever they have settled [101,102]. Beyond their presence, growing research shows how these species have a negative impact on native wildlife, thereby converting themselves into conflictive invasive species $[103,104]$. In the case of cities, the presence of cats and dogs (domestic or feral) may increase spatial-use conflicts with wildlife in urban green areas $[105,106]$, also affecting native mammal, bird, reptile and amphibian communities by predation [107]. Finally, the high densities of these species can threaten public health by increasing the prevalence of diseases such as toxoplasma and rabies [108,109].

\section{Conclusions}

The expanding trend of urbanization, especially in developing countries $[110,111]$ will likely lead to an increasing number of carnivores interacting in cities, due to the high availability of prey, garbage and organic remains, especially in countries with poor waste management practices. We also consider that, as the number of studies increases, more synanthropic species of medium and small size will be reported among the lists of carnivores exploiting cities, especially for those cities and countries for which we do not yet have scientific studies on urban predators and scavengers. Beyond birds and mammals, a priori, there are few options from other animal groups scavenging in cities, with the exception of some large reptiles. As such, the occurrence of different large monitor lizards (mainly Varanus salvator and Varanus benghalensis) in Asian cities may be an interesting topic to study in the coming years, attending to the role that they play as scavengers, and the potential conflict generated due to their presence. In general, we urge researchers to continue studying urban carnivores' diet, expanding their research to more species and regions with less scientific information. In addition, from the point of view of urban ecology, a greater knowledge of predators and scavengers would help to improve our understanding of the relationship between carnivores and their environment, in the case of human-dominated areas such as cities. Thus, future studies on predators and scavengers 
in cities should not only focus on the type of food urban carnivores consume but also on the location and distribution of meat resources within urban areas, their availability and predictability, and how these features influence the ecology of these species. Finally, a more complete comprehension of the presence of carnivores in urban areas may help to better inform citizens and mitigate conflicts with residents, improving the perception and acceptance of carnivores in urbanized areas, and, by extension, fostering an improved attitude toward nature in a broader sense.

Supplementary Materials: The following are available online at https: / www.mdpi.com/1424-2 818/13/2/46/s1, Table S1: Articles recorded during the urban predation search, Table S2: Articles recorded during the urban scavenging search, Table S3: Articles recorded in the urban predation review, Table S4: Articles recorded in the urban scavenging.

Author Contributions: Conceptualization, Á.L., P.R.-V. and E.A.; methodology, Á.L., P.R.-V. and E.A.; formal analysis E.A.; investigation, Á.L., P.R.-V. and E.A.; data curation, Á.L. and E.A.; writingoriginal draft preparation, Á.L.; writing-review and editing, Á.L., P.R.-V. and E.A.; visualization, Á.L., P.R.-V. and E.A.; supervision, Á.L., P.R.-V. and E.A. All authors have read and agreed to the published version of the manuscript.

Funding: The research was funded by RTI2018-099609-B-C21 (Spanish Ministry of Economy and Competitiveness and EU/ERDF).

Institutional Review Board Statement: Not applicable.

Informed Consent Statement: Not applicable.

Data Availability Statement: The data presented in this study are available in supplementary material.

Acknowledgments: We thank Ana Benítez (Doñana Biological Station) for her help and useful suggestions. The four anonymous reviewer made very valuable comments that greatly improved the manuscript, and Corrine O'Sullivan and Wouter Marc Gerard Vansteelant revised the English.

Conflicts of Interest: The authors declare no conflict of interest. The funders had no role in the design of the study; in the collection, analyses, or interpretation of data; in the writing of the manuscript, or in the decision to publish the results.

\section{References}

1. Dearborn, D.C.; Kark, S. Motivations for conserving urban biodiversity. Conserv. Biol. 2010, 24, 432-440. [CrossRef]

2. Aronson, M.F.; La Sorte, F.A.; Nilon, C.H.; Katti, M.; Goddard, M.A.; Lepczyk, C.A.; Warren, P.S.; Williams, N.S.; Cilliers, S.; Clarkson, B.; et al. A global analysis of the impacts of urbanization on bird and plant diversity reveals key anthropogenic drivers. Proc. R. Soc. B 2014, 281, 20133330. [CrossRef]

3. Braaker, S.; Ghazoul, J.; Obrist, M.K.; Moretti, M. Habitat connectivity shapes urban arthropod communities: The key role of green roofs. Ecology 2014, 95, 1010-1021. [CrossRef]

4. Threlfall, C.G.; Walker, K.; Williams, N.S.; Hahs, A.K.; Mata, L.; Stork, N.; Livesley, S.J. The conservation value of urban green space habitats for Australian native bee communities. Biol. Conserv. 2015, 187, 240-248. [CrossRef]

5. Clergeau, P.; Croci, S.; Jokimäki, J.; Kaisanlahti-Jokimäki, M.L.; Dinetti, M. Avifauna homogenisation by urbanisation: Analysis at different European latitudes. Biol. Conserv. 2006, 127, 336-344. [CrossRef]

6. Ortega-Álvarez, R.; MacGregor-Fors, I. Living in the big city: Effects of urban land-use on bird community structure, diversity, and composition. Landsc. Urban Plan. 2009, 90, 189-195. [CrossRef]

7. Faeth, S.H.; Bang, C.; Saari, S. Urban biodiversity: Patterns and mechanisms. Ann. N. Y. Acad. Sci. 2011, 1223, 69-81. [CrossRef]

8. Rebolo-Ifrán, N.; Tella, J.L.; Carrete, M. Urban conservation hotspots: Predation release allows the grassland-specialist burrowing owl to perform better in the city. Sci. Rep. 2017, 7, 1-9. [CrossRef]

9. Recio, M.R.; Payne, K.; Seddon, P.J. Emblematic forest dwellers reintroduced into cities: Resource selection by translocated juvenile kaka. Curr. Zool. 2016, 62, 15-22. [CrossRef]

10. Luna, Á.; Romero-Vidal, P.; Hiraldo, F.; Tella, J.L. Cities may save some threatened species but not their ecological functions. PeerJ 2018, 6, e4908. [CrossRef]

11. Soanes, K.; Lentini, P.E. When cities are the last chance for saving species. Front. Ecol. Environ. 2019, 17, 225-231. [CrossRef]

12. Thomas, J.P.; Jung, T.S. Life in a northern town: Rural villages in the boreal forest are islands of habitat for an endangered bat. Ecosphere 2019, 10, e02563. [CrossRef]

13. Kinzig, A.P.; Warren, P.; Martin, C.; Hope, D.; Katti, M. The effects of human socioeconomic status and cultural characteristics on urban patterns of biodiversity. Ecol. Soc. 2005, 10, 1-13. [CrossRef] 
14. Lepczyk, C.A.; Aronson, M.F.; Evans, K.L.; Goddard, M.A.; Lerman, S.B.; MacIvor, J.S. Biodiversity in the city: Fundamental questions for understanding the ecology of urban green spaces for biodiversity conservation. BioScience 2017, 67, 799-807. [CrossRef]

15. Cardoso, G.C.; Klingbeil, B.T.; La Sorte, F.A.; Lepczyk, C.A.; Fink, D.; Flather, C.H. Exposure to noise pollution across North American passerines supports the noise filter hypothesis. Glob. Ecol. Biogeogr. 2020, 29, 1430-1434. [CrossRef]

16. Gaston, K.J.; Visser, M.E.; Hölker, F. The biological impacts of artificial light at night: The research challenge. Philos. Trans. R. Soc. B 2015, 370, 20140133. [CrossRef]

17. Ciach, M.; Fröhlich, A. Habitat preferences of the Syrian Woodpecker Dendrocopos syriacus in urban environments: An ambiguous effect of pollution. Bird Study 2013, 60, 491-499. [CrossRef]

18. Foltz, S.L.; Ross, A.E.; Laing, B.T.; Rock, R.P.; Battle, K.E.; Moore, I.T. Get off my lawn: Increased aggression in urban song sparrows is related to resource availability. Behav. Ecol. 2015, 26, 1548-1557. [CrossRef]

19. Kark, S.; Iwaniuk, A.; Schalimtzek, A.; Banker, E. Living in the city: Can anyone become an 'urban exploiter'? J. Biogeogr. 2007, 34, 638-651. [CrossRef]

20. Møller, A.P. Successful city dwellers: A comparative study of the ecological characteristics of urban birds in the Western Palearctic. Oecologia 2009, 159, 849-858. [CrossRef]

21. Evans, K.L.; Chamberlain, D.E.; Hatchwell, B.J.; Gregory, R.D.; Gaston, K.J. What makes an urban bird? Glob. Chang. Biol. 2011, 7, 32-44. [CrossRef]

22. Leveau, L.M. Bird traits in urban-rural gradients: How many functional groups are there? J. Ornithol. 2013, 154, 655-662. [CrossRef]

23. Baker, P.J.; Ansell, R.J.; Dodds, P.A.A.; Webber, C.E.; Harris, S. Factors affecting the distribution of small mammals in an urban area. Mammal Rev. 2003, 33, 95-100. [CrossRef]

24. Santini, L.; González-Suárez, M.; Russo, D.; Gonzalez-Voyer, A.; von Hardenberg, A.; Ancillotto, L. One strategy does not fit all: Determinants of urban adaptation in mammals. Ecol. Lett. 2019, 22, 365-376. [CrossRef]

25. Lowry, H.; Lill, A.; Wong, B.B. Behavioural responses of wildlife to urban environments. Biol. Rev. 2013, 88, 537-549. [CrossRef]

26. Murray, M.; Cembrowski, A.; Latham, A.D.M.; Lukasik, V.M.; Pruss, S.; St Clair, C.C. Greater consumption of protein-poor anthropogenic food by urban relative to rural coyotes increases diet breadth and potential for human-wildlife conflict. Ecography 2015, 38, 1235-1242. [CrossRef]

27. de Araujo, G.M.; Peres, C.A.; Baccaro, F.B.; Guerta, R.S. Urban waste disposal explains the distribution of Black Vultures (Coragyps atratus) in an Amazonian metropolis: Management implications for birdstrikes and urban planning. PeerJ 2018, 6, e5491. [CrossRef]

28. Houston, D.C.; Mee, A.; McGrady, M. Why do condors and vultures eat junk?: The implications for conservation. J. Raptor Res. 2007, 41, 235-238. [CrossRef]

29. Oro, D.; Genovart, M.; Tavecchia, G.; Fowler, M.S.; Martínez-Abraín, A. Ecological and evolutionary implications of food subsidies from humans. Ecol. Lett. 2013, 16, 1501-1514. [CrossRef]

30. Plaza, P.I.; Lambertucci, S.A. How are garbage dumps impacting vertebrate demography, health, and conservation? Glob. Ecol. Conserv. 2017, 12, 9-20. [CrossRef]

31. Hindmarch, S.; Elliott, J.E. When owls go to town: The diet of urban Barred Owls. J. Raptor. Res. 2015, 49, 66-74. [CrossRef]

32. McPherson, S.C.; Brown, M.; Downs, C.T. Diet of the crowned eagle (Stephanoaetus coronatus) in an urban landscape: Potential for human-wildlife conflict? Urban Ecosyst. 2016, 19, 383-396. [CrossRef]

33. Bateman, P.W.; Fleming, P.A. Big city life: Carnivores in urban environments. J. Zool. 2012, 287, 1-23. [CrossRef]

34. Newsome, S.D.; Garbe, H.M.; Wilson, E.C.; Gehrt, S.D. Individual variation in anthropogenic resource use in an urban carnivore. Oecologia 2015, 178, 115-128. [CrossRef] [PubMed]

35. Bildstein, K.L.; Therrien, J.F. Urban birds of prey: A lengthy history of human-raptor cohabitation. In Urban Raptors; Island Press: Washington, DC, USA, 2018; pp. 3-17.

36. Contesse, P.; Hegglin, D.; Gloor, S.; Bontadina, F.; Deplazes, P. The diet of urban foxes (Vulpes vulpes) and the availability of anthropogenic food in the city of Zurich, Switzerland. Mamm. Biol. 2004, 69, 81-95. [CrossRef]

37. Kristan, W.B., III; Boarman, W.I.; Crayon, J.J. Diet composition of common ravens across the urban-wildland interface of the West Mojave Desert. Wildl. Soc. Bull. 2004, 32, 244-253. [CrossRef]

38. Allen, B.L.; Carmelito, E.; Amos, M.; Goullet, M.S.; Allen, L.R.; Speed, J.; Leung, L.K.P. Diet of dingoes and other wild dogs in peri-urban areas of north-eastern Australia. Sci. Rep. 2016, 6, 1-8. [CrossRef]

39. Morgan, S.A.; Hansen, C.M.; Ross, J.G.; Hickling, G.J.; Ogilvie, S.C.; Paterson, A.M. Urban cat (Felis catus) movement and predation activity associated with a wetland reserve in New Zealand. Wild. Res. 2009, 36, 574-580. [CrossRef]

40. Henriques, M.; Granadeiro, J.P.; Hamilton Monteiro, A.N.; Lecoq, M.; Cardoso, P.; Regalla, A.; Catry, P. Not in wilderness: African vulture strongholds remain in areas with high human density. PLoS ONE 2018, 13, e0190594. [CrossRef]

41. Larson, R.N.; Morin, D.J.; Wierzbowska, I.A.; Crooks, K.R. Food habits of coyotes, gray foxes, and bobcats in a coastal southern California urban landscape. West. N. Am. Nat. 2015, 75, 339-347. [CrossRef]

42. Méndez, A.; Montalvo, T.; Aymí, R.; Carmona, M.; Figuerola, J.; Navarro, J. Adapting to urban ecosystems: Unravelling the foraging ecology of an opportunistic predator living in cities. Urban Ecosyst. 2020, 23, 1117-1126. [CrossRef] 
43. Sims, V.; Evans, K.L.; Newson, S.E.; Tratalos, J.A.; Gaston, K.J. Avian assemblage structure and domestic cat densities in urban environments. Divers. Distrib. 2008, 14, 387-399. [CrossRef]

44. Drewitt, E.J.; Dixon, N. Diet and prey selection of urban-dwelling Peregrine Falcons in southwest England. Br. Birds 2008, 101, 58.

45. Braczkowski, A.R.; O’Bryan, C.J.; Stringer, M.J.; Watson, J.E.; Possingham, H.P.; Beyer, H.L. Leopards provide public health benefits in Mumbai, India. Front. Ecol. Environ. 2018, 16, 176-182. [CrossRef]

46. Shochat, E.; Warren, P.S.; Faeth, S.H.; McIntyre, N.E.; Hope, D. From patterns to emerging processes in mechanistic urban ecology. Trends Ecol. Evol. 2006, 21, 186-191. [CrossRef]

47. Rodewald, A.D.; Kearns, L.J.; Shustack, D.P. Anthropogenic resource subsidies decouple predator-prey relationships. Ecol. App. 2011, 21, 936-943. [CrossRef]

48. Fischer, J.D.; Cleeton, S.H.; Lyons, T.P.; Miller, J.R. Urbanization and the predation paradox: The role of trophic dynamics in structuring vertebrate communities. Bioscience 2012, 62, 809-818. [CrossRef]

49. Inger, R.; Cox, D.T.; Per, E.; Norton, B.A.; Gaston, K.J. Ecological role of vertebrate scavengers in urban ecosystems in the UK. Ecol. Evol. 2016, 6, 7015-7023. [CrossRef]

50. Schwartz, A.L.; Williams, H.F.; Chadwick, E.; Thomas, R.J.; Perkins, S.E. Roadkill scavenging behaviour in an urban environment. J. Urban Ecol. 2018, 4, juy006. [CrossRef]

51. Plaza, P.I.; Lambertucci, S.A. More massive but potentially less healthy: Black vultures feeding in rubbish dumps differed in clinical and biochemical parameters with wild feeding birds. PeerJ 2018, 6, e4645. [CrossRef]

52. Lambertucci, S.A.; Speziale, K.L.; Rogers, T.E.; Morales, J.M. How do roads affect the habitat use of an assemblage of scavenging raptors? Biodivers. Conserv. 2009, 18, 2063-2074. [CrossRef]

53. Arrondo, E.; Sanz-Aguilar, A.; Pérez-García, J.M.; Cortés-Avizanda, A.; Sánchez-Zapata, J.A.; Donázar, J.A. Landscape anthropization shapes the survival of a top avian scavenger. Biodivers. Conserv. 2020, 29, 1411-1425. [CrossRef]

54. Ogada, D.L.; Keesing, F.; Virani, M.Z. Dropping dead: Causes and consequences of vulture population declines worldwide. Ann. N. Y. Acad. Sci. 2012, 1249, 57-71. [CrossRef] [PubMed]

55. Buechley, E.R.; McGrady, M.J.; Çoban, E.; Şekercioğlu, Ç.H. Satellite tracking a wide-ranging endangered vulture species to target conservation actions in the Middle East and East Africa. Biodivers. Conserv. 2018, 27, 2293-2310. [CrossRef]

56. Novaes, W.G.; Abreu, T.L.D.S.; Guerta, R.S. Assessing vulture translocation as a management tool to mitigate airport bird strikes. Hum.-Wildl. Interact. 2020, 14, 19.

57. Parra, J.; Tellería, J.L. The increase in the Spanish population of Griffon Vulture Gyps fulvus during 1989-1999: Effects of food and nest site availability. Bird Conserv. Int. 2004, 14, 33-41. [CrossRef]

58. Moleón, M.; Sanchez-Zapata, J.A.; Margalida, A.; Carrete, M.; Owen-Smith, N.; Donazar, J.A. Humans and scavengers: The evolution of interactions and ecosystem services. BioScience 2014, 64, 394-403. [CrossRef]

59. McDonnell, M.J.; Niemelä, J. The history of urban ecology. Urban Ecol. 2011, 9, 34-49.

60. Magle, S.B.; Hunt, V.M.; Vernon, M.; Crooks, K.R. Urban wildlife research: Past, present, and future. Biol. Conserv. 2012, 155, 23-32. [CrossRef]

61. McPhearson, T.; Pickett, S.T.; Grimm, N.B.; Niemelä, J.; Alberti, M.; Elmqvist, T.; Qureshi, S. Advancing urban ecology toward a science of cities. BioScience 2016, 66, 198-212. [CrossRef]

62. DeVault, T.L.; Rhodes, O.E., Jr.; Shivik, J.A. Scavenging by vertebrates: Behavioral, ecological, and evolutionary perspectives on an important energy transfer pathway in terrestrial ecosystems. Oikos 2003, 102, 225-234.

63. Cincotta, R.P.; Wisnewski, J.; Engelman, R. Human population in the biodiversity hotspots. Nature 2000, 404, 990-992. [CrossRef] [PubMed]

64. Bradshaw, C.J.; Sodhi, N.S.; Brook, B.W. Tropical turmoil: A biodiversity tragedy in progress. Front. Ecol. Environ. 2009, 7, 79-87. [CrossRef]

65. Haddaway, N.R.; Woodcock, P.; Macura, B.; Collins, A. Making literature reviews more reliable through application of lessons from systematic reviews. Conserv. Biol. 2015, 29, 1596-1605. [CrossRef] [PubMed]

66. Lozano, J.; Olszańska, A.; Morales-Reyes, Z.; Castro, A.A.; Malo, A.F.; Moleón, M.; Sánchez-Zapata, J.A.; Cortés-Avizanda, A.; von Wehrden, H.; Dorresteijn, I.; et al. Human-carnivore relations: A systematic review. Biol. Conserv. 2019, 237, 480-492. [CrossRef]

67. Haddaway, N.R.; Bayliss, H.R. Shades of grey: Two forms of grey literature important for reviews in conservation. Biol. Conserv. 2015, 191, 827-829. [CrossRef]

68. Paez, A. Gray literature: An important resource in systematic reviews. J. Evid. Based. Med. 2017, 10, 233-240. [CrossRef]

69. Olson, D.M.; Dinerstein, E.; Wikramanayake, E.D.; Burgess, N.D.; Powell, G.V.N.; Underwood, E.C.; D'amico, J.A.; Itoua, I.; Strand, H.E.; Morrison, J.C.; et al. Terrestrial Ecoregions of the World: A New Map of Life on Earth: A new global map of terrestrial ecoregions provides an innovative tool for conserving biodiversity. BioScience 2001, 51, 933-938. [CrossRef]

70. Wilman, H.; Belmaker, J.; Simpson, J.; de la Rosa, C.; Rivadeneira, M.M.; Jetz, W. EltonTraits 1.0: Species-level foraging attributes of the world's birds and mammals: Ecological Archives E095-178. Ecology 2014, 95, 2027. [CrossRef]

71. Shine, R.; Harlow, P.S. Ecological traits of commercially harvested water monitors, Varanus salvator, in northern Sumatra. Wildl. Res. 1998, 25, 437-447. [CrossRef]

72. Guarino, F. Diet of a large carnivorous lizard, Varanus varius. Wildl. Res. 2001, 28, 627-630. [CrossRef]

73. Guarino, F. Spatial ecology of a large carnivorous lizard, Varanus varius (Squamata: Varanidae). J. Zool. 2002, 258, 449-457. [CrossRef] 
74. Martins, F.I.; De Souza, F.L.; Da Costa, H.T.M. Feeding habits of Phrynops geoffroanus (Chelidae) in an urban river in Central Brazil. Chelonian Conserv. Biol. 2010, 9, 294-297. [CrossRef]

75. Balakrishna, S.; Batabyal, A.; Thaker, M. Dining in the city: Dietary shifts in Indian rock agamas across an urban-rural landscape. J. Herpetol. 2016, 50, 423-428. [CrossRef]

76. Burnham, K.P.; Anderson, D.R. Model Selection and Multimodel Inference: A Practical Information-Theoretic Approach (2 $\left.{ }^{a}\right)$, Ecological Modelling; Springer Science \& Business Media: Berlin/Heidelberg, Germany, 2002.

77. Arnold, T.W. Uninformative parameters and model selection using Akaike's Information Criterion. J. Wildl. Manag. 2010, 74, 1175-1178. [CrossRef]

78. Kleiber, C.; Zeileis, A. Applied Econometrics with R; Springer: New York, NY, USA, 2008; ISBN 978-0-387-77316-2.

79. R Development Core Team. R: A Language and Environment for Statistical Computing (R-3.6.1); R Foundation for StatisticalComputing: Vienna, Austria, 2019.

80. Sazima, I. Australian Raven (Corvus coronoides) scavenges on all five major vertebrate groups at urban Sydney, Southeast Australia. Trop. Nat. Hist. 2020, 20, 89-94.

81. Clifton, B.; Jones, D.N. Finding food in a human-dominated environment: Exploring the foraging behaviour of urban Torresian Crows' Corvus orru'. Aust. Field Ornithol. 2017, 34, 30. [CrossRef]

82. Schlacher, T.A.; Weston, M.A.; Lynn, D.; Schoeman, D.S.; Huijbers, C.M.; Olds, A.D.; Connolly, R.M. Conservation gone to the dogs: When canids rule the beach in small coastal reserves. Biodivers. Conserv. 2015, 24, 493-509. [CrossRef]

83. Welti, N.; Scherler, P.; Grüebler, M.U. Carcass predictability but not domestic pet introduction affects functional response of scavenger assemblage in urbanized habitats. Funct. Ecol. 2020, 34, 265-275. [CrossRef]

84. $\mathrm{Wu}, \mathrm{J}$. Urban ecology and sustainability: The state-of-the-science and future directions. Landsc. Urban Plan. 2014, 125, $209-221$. [CrossRef]

85. Beasley, J.C.; Olson, Z.H.; DeVault, T.L. Ecological role of vertebrate scavengers. In Carrion Ecology, Evolution and Their Applications, 1st ed.; Eric, B., Jeffery, K.T., Aaron, M.T., Eds.; CRC Press: Cleveland, OH, USA, 2015; pp. 107-127.

86. King, D. The scientific impact of nations. Nature 2004, 430, 311-316. [CrossRef]

87. Hoornweg, D.; Bhada-Tata, P. What a waste: A global review of solid waste management. Urban development series; knowledge papers no. 15. World Bank: Washington, DC, USA, 2012.

88. Mudzengerere, F.H.; Chigwenya, A. Waste Management in Bulawayo city council in Zimbabwe: In search of Sustainable waste Management in the city. J. Sustain. Dev. Afr. 2012, 14, 228-244.

89. Abay, G.Y.; Bauer, H.; Gebrihiwot, K.; Deckers, J. Peri-urban spotted hyena (Crocuta crocuta) in northern Ethiopia: Diet, economic impact, and abundance. Eur. J. Wildl. Res. 2011, 57, 759-765. [CrossRef]

90. Sol, D.; Gonzalez-Lagos, C.; Moreira, D.; Maspons, J. Urbanisation tolerance and the loss of avian diversity. Ecol. Lett. 2014, 17, 942-950. [CrossRef]

91. Carrete, M.; Tella, J.L. Behavioral correlations associated with fear of humans differ between rural and urban burrowing owls. Front. Ecol. Evol. 2017, 5, 54. [CrossRef]

92. Beninde, J.; Veith, M.; Hochkirch, A. Biodiversity in cities needs space: A meta-analysis of factors determining intra-urban biodiversity variation. Ecol. Lett. 2015, 18, 581-592. [CrossRef] [PubMed]

93. Iserhard, C.A.; Duarte, L.; Seraphim, N.; Freitas, A.V.L. How urbanization affects multiple dimensions of biodiversity in tropical butterfly assemblages. Biodivers. Conserv. 2019, 28, 621-638. [CrossRef]

94. Huijbers, C.M.; Schlacher, T.A.; Schoeman, D.S.; Weston, M.A.; Connolly, R.M. Urbanisation alters processing of marine carrion on sandy beaches. Landsc Urban Plan. 2013, 119, 1-8. [CrossRef]

95. Riding, C.S.; Loss, S.R. Factors influencing experimental estimation of scavenger removal and observer detection in bird-window collision surveys. Ecol. Appl. 2018, 28, 2119-2129. [CrossRef]

96. Kulabtong, S.; Mahaprom, R. Observation on food items of Asian water monitor, Varanus salvator (Laurenti, 1768) (Squamata Varanidae), in urban eco-system, Central Thailand. Biodivers. J. 2014, 6, 695-698.

97. Rahman, K.M.; Khan, M.M.H.; Rakhimov, I.I. Scavenging Behavior of the Bengal Monitor (Varanus bengalensis) in Jahangirnagar University Campus, Bangladesh. J. Sci. Res. Rep. 2015, 539-550. [CrossRef]

98. Karanth, K.U.; Gopal, R. An ecology-based policy framework for human-tiger coexistence in India. Conserv. Biol. Ser.-Camb. 2005, 9, 373-387.

99. Meena, V.; Jhala, Y.V.; Chellam, R.; Pathak, B. Implications of diet composition of Asiatic lions for their conservation. J. Zool. 2011, 284, 60-67. [CrossRef]

100. Kumbhojkar, S.; Yosef, R.; Kosicki, J.Z.; Kwiatkowska, P.K.; Tryjanowski, P. Dependence of the leopard Panthera pardus fusca in Jaipur, India, on domestic animals. Oryx 2020, 1-7. [CrossRef]

101. Medina, F.M.; Bonnaud, E.; Vidal, E.; Tershy, B.R.; Zavaleta, E.S.; Josh Donlan, C.; Nogales, M. A global review of the impacts of invasive cats on island endangered vertebrates. Glob. Chang. Biol. 2011, 17, 3503-3510. [CrossRef]

102. Young, J.K.; Olson, K.A.; Reading, R.P.; Amgalanbaatar, S.; Berger, J. Is wildlife going to the dogs? Impacts of feral and free-roaming dogs on wildlife populations. Bioscience 2011, 61, 125-132. [CrossRef]

103. Loss, S.R.; Will, T.; Marra, P.P. The impact of free-ranging domestic cats on wildlife of the United States. Nat. Commun. 2013, 4, 1-8. [CrossRef] 
104. Hughes, J.; Macdonald, D.W. A review of the interactions between free-roaming domestic dogs and wildlife. Biol. Conserv. 2013, 157, 341-351. [CrossRef]

105. Coronel-Arellano, H.; Rocha-Ortega, M.; Gual-Sill, F.; Martínez-Meyer, E.; Ramos-Rendón, A.K.; González-Negrete, M.; Zambrano, L. Raining feral cats and dogs? Implications for the conservation of medium-sized wild mammals in an urban protected area. Urban Ecosyst. 2020, 1-12. [CrossRef]

106. Mella-Méndez, I.; Flores-Peredo, R.; Bolívar-Cimé, B.; Vázquez-Domínguez, G. Effect of free-ranging dogs and cats on mediumsized wild mammal assemblages in urban protected areas of a Mexican city. Wildl. Res. 2020, 46, 669-678. [CrossRef]

107. Seymour, C.L.; Simmons, R.E.; Morling, F.; George, S.T.; Peters, K.; O'Riain, M.J. Caught on camera: The impacts of urban domestic cats on wild prey in an African city and neighbouring protected areas. Glob. Ecol. Conserv. 2020, 23, e01198. [CrossRef]

108. Markandya, A.; Taylor, T.; Longo, A.; Murty, M.N.; Murty, S.; Dhavala, K. Counting the cost of vulture decline-an appraisal of the human health and other benefits of vultures in India. Ecol. Econ. 2008, 67, 194-204. [CrossRef]

109. Lepczyk, C.A.; Haman, K.H.; Sizemore, G.C.; Farmer, C. Quantifying the presence of feral cat colonies and Toxoplasma gondii in relation to bird conservation areas on O'ahu, Hawai'i. Conserv. Sci. Pract. 2020, 2, e179. [CrossRef]

110. Seto, K.C.; Güneralp, B.; Hutyra, L.R. Global forecasts of urban expansion to 2030 and direct impacts on biodiversity and carbon pools. Proc. Natl. Acad. Sci. USA 2012, 109, 16083-16088. [CrossRef]

111. Chen, G.; Li, X.; Liu, X.; Chen, Y.; Liang, X.; Leng, J.; Xu, X.; Liao, W.; Qiu, Y.; Wu, Q.; et al. Global projections of future urban land expansion under shared socioeconomic pathways. Nat. Commun. 2020, 11, 1-12. [CrossRef] [PubMed] 